\title{
Cytotoxic CD8-positive T-lymphocyte infiltration in the lungs as a histological pattern of SARS-CoV-2 pneumonitis
}

\author{
Andrit Puzyrenko, Juan C. Felix, Nathan A. Ledeboer, Yunguang Sun, \\ Hallgeir Rui, Yuri SHeinin
}

Medical College of Wisconsin, Pathology Department, Milwaukee, WI, USA

\begin{abstract}
Summary
Despite millions of PCR confirmed cases of severe acute respiratory syndrome coronavirus-2 (SARS-CoV-2) infection, the long-term pathophysiological changes induced by this infection in the lungs and their relationship with possible immune triggers remain incompletely understood. Acute respiratory distress syndrome and subsequent respiratory failure are the most common causes of mortality in hospitalised patients. Severe lung tissue destruction can be due to an overactive immune system that far exceeds the harm that would have been caused by direct virus replication. This study extends our previous investigation and presents detailed histopathological findings on cryotransbronchial biopsy in patients with persistent (range 31-182 days) pneumonitis and severe interstitial inflammatory infiltration in the lungs due to SARS-CoV-2 infection. We describe a novel lung injury pattern associated with SARSCoV-2 pneumonitis, which manifests as a marked interstitial CD8-positive T-cell lymphocytic infiltration. These findings provide a better understanding of the changes in the lungs that ensue due to SARS-CoV-2 infection.
\end{abstract}

Key words: SARS-CoV-2; pneumonitis; CD8-positive T-lymphocytes; COVID-19.

Received 18 June, revised 5 August, accepted 6 September 2021 Available online 8 November 2021

\section{INTRODUCTION}

The 2019 novel coronavirus (COVID-19) has had a significant impact on practically everyone. Despite millions of polymerase chain reaction (PCR) confirmed cases of severe acute respiratory syndrome coronavirus-2 (SARS-CoV-2) infection, the long-term pathophysiological changes induced by this infection in the lungs and their relationship with possible immune triggers remain incompletely understood. This study extends our previous investigation ${ }^{1}$ and describes the histological pattern in antemortem lung tissue after cryotransbronchial biopsy in an additional eight cases of SARS-CoV-2 infection with persistent (range 31-182 days) interstitial inflammatory infiltrates and pneumonitis.

\section{MATERIALS AND METHODS}

Between August 2020 and March 2021, histological lung specimens were obtained from eight SARS-CoV-2-positive patients for antemortem evaluation after bronchoscopy and cryotransbronchial biopsy. The clinical records, radiological, and pathological findings were retrospectively compiled. Transbronchial biopsy specimens were available in all patients, taken from the most prominent areas of the interstitial ground-glass opacities. The mean number of lung biopsy fragments per case was three (range 2-4).

Biopsy specimens were fixed in $10 \%$ formalin, embedded in paraffin wax, and sectioned at $5 \mu \mathrm{m}$. Sections were stained with haematoxylin and eosin. Each biopsy specimen was evaluated semi-quantitatively for the following parameters: the presence or absence of reactive pneumocytes; alveolar macrophages; lymphocytes; neutrophils; plasma cells, fibroblastic foci; peribronchiolar inflammation; and viral cytopathic effect.

Immunohistochemical labelling was performed with antibodies directed against the following proteins: CD3 (antiCD3; Leica Biosystems, UK); CD4 (anti-CD4; Leica Biosystems); CD8 (anti-CD8; Leica Biosystems); CD20 (antiCD20; Leica Biosystems); and SARS-CoV-2 nucleocapsid protein. ${ }^{2}$ CD4 and CD8 staining were scored as percentpositive immune cell: 0 , negative; $1,1-30 \% ; 2,31-70 \%$; and 3, 71-100\% positive immune cell.

\section{RESULTS}

\section{Clinical findings}

A summary of the clinical and endoscopic findings from eight patients ( 5 men and 3 women) is provided in Table 1. The patients' age ranged from 41-69 years with a mean of 55 years. Three patients had underlying lymphomas but were in clinical remission, two patients had autoimmune disorders and were taking immunosuppressive therapy, and the remaining three patients did not have comorbid diseases related to the immune system. All eight patients tested positive for SARS-CoV-2 by real-time PCR using nasal swab samples at the time of clinical symptom onset and chest computed tomography (CT) exhibited peripheral patchy and heterogeneous ground-glass opacities consistent with SARSCoV-2 pneumonia.

For all cases, bronchoscopy was performed to explore persistent extensive interstitial ground-glass opacities in the lungs on the CT studies that were associated with shortness of breath (minimum of 1 month and maximum of 6 months). Endoscopic examination of the respiratory system showed normal airway mucosa except for Case 8, where bronchoscopy 
Table 1 SARS-CoV-2 pneumonitis: clinical findings in eight cases of the present series

\begin{tabular}{|c|c|c|c|c|c|c|c|c|c|}
\hline Case & $\begin{array}{l}\text { Age, } \\
\text { sex }\end{array}$ & $\begin{array}{l}\text { Comorbids related to the } \\
\text { immune system }\end{array}$ & Treatment prior to bronchoscopy $\mathrm{y}^{\mathrm{a}}$ & $\begin{array}{l}\text { SARS-CoV-2 } \\
\text { IgG within } 7 \\
\text { days of biopsy }\end{array}$ & $\begin{array}{c}\text { PCR at } \\
\text { disease } \\
\text { onset }\end{array}$ & $\begin{array}{l}\text { PCR within } \\
7 \text { days of } \\
\text { biopsy }^{\mathrm{a}}\end{array}$ & Chest $\mathrm{CT}$ at disease onset & $\begin{array}{l}\text { Chest CT within } 7 \\
\text { days of biopsy }^{\mathrm{a}}\end{array}$ & Bronchoscopy \\
\hline 1 & $49, \mathrm{M}$ & CLL, in clinical remission & $\begin{array}{l}\text { Oxygen, voriconazole, TMP-SMX, } \\
\text { acyclovir }\end{array}$ & Non-reactive & Positive & Negative & $\begin{array}{l}\text { Interstitial ground-glass } \\
\text { opacities in the left } \\
\text { midlung }\end{array}$ & $\begin{array}{l}\text { Bilateral interstitial } \\
\text { ground-glass } \\
\text { opacities }\end{array}$ & $\begin{array}{l}\text { Normal airway mucosa } \\
\quad \text { (on 31st day) }\end{array}$ \\
\hline 2 & $44, \mathrm{~F}$ & $\begin{array}{l}\text { Sjögren and Hashimoto, on } \\
\text { immune suppression }\end{array}$ & $\begin{array}{l}\text { No indication for antimicrobial } \\
\text { treatment rituximab, azathioprine }\end{array}$ & Non-reactive & Positive & Negative & $\begin{array}{l}\text { Bilateral interstitial } \\
\text { ground-glass opacities }\end{array}$ & $\begin{array}{l}\text { Bilateral interstitial } \\
\text { ground-glass } \\
\text { opacities }\end{array}$ & $\begin{array}{l}\text { Normal airway mucosa } \\
\text { (on 93rd day) }\end{array}$ \\
\hline 3 & $61, \mathrm{~F}$ & N/A & $\begin{array}{l}\text { No indication for antimicrobial } \\
\text { treatment }\end{array}$ & Non-reactive & Positive & Negative & $\begin{array}{l}\text { Bilateral interstitial } \\
\text { ground-glass opacities }\end{array}$ & $\begin{array}{l}\text { Bilateral interstitial } \\
\text { ground-glass } \\
\text { opacities }\end{array}$ & $\begin{array}{l}\text { Normal airway mucosa } \\
\quad \text { (on 182nd day) }\end{array}$ \\
\hline 4 & $68, \mathrm{M}$ & N/A & Oxygen, prednisone & Non-reactive & Positive & Negative & $\begin{array}{l}\text { Bilateral interstitial } \\
\text { ground-glass opacities }\end{array}$ & $\begin{array}{l}\text { Bilateral interstitial } \\
\text { ground-glass } \\
\text { opacities }\end{array}$ & $\begin{array}{l}\text { Normal airway mucosa } \\
\text { (on 90th day) }\end{array}$ \\
\hline 5 & $41, \mathrm{M}$ & $\begin{array}{l}\text { Follicular lymphoma, in } \\
\text { clinical remission }\end{array}$ & $\begin{array}{l}\text { Dexamethasone, oxygen, convalescent } \\
\text { plasma, TMP-SMX,acyclovir }\end{array}$ & Non-reactive & Positive & Negative & $\begin{array}{l}\text { Bilateral interstitial } \\
\text { ground-glass opacities }\end{array}$ & $\begin{array}{l}\text { Bilateral interstitial } \\
\text { ground-glass } \\
\text { opacities }\end{array}$ & $\begin{array}{l}\text { Normal airway mucosa } \\
\quad \text { (on 35th day) }\end{array}$ \\
\hline 6 & $53, \mathrm{M}$ & N/A & Oxygen & Non-reactive & Positive & Negative & $\begin{array}{l}\text { Bilateral interstitial } \\
\text { ground-glass opacities }\end{array}$ & $\begin{array}{l}\text { Bilateral interstitial } \\
\text { ground-glass } \\
\text { opacities }\end{array}$ & $\begin{array}{l}\text { Normal airway mucosa } \\
\text { (on 37th day) }\end{array}$ \\
\hline 7 & $58, \mathrm{M}$ & $\begin{array}{l}\text { Follicular lymphoma, in } \\
\text { clinical remission }\end{array}$ & Dexamethasone, TMP-SMX & Non-reactive & Positive & Positive & $\begin{array}{l}\text { Bilateral interstitial } \\
\text { ground-glass opacities }\end{array}$ & $\begin{array}{l}\text { Bilateral interstitial } \\
\text { ground-glass } \\
\text { opacities }\end{array}$ & $\begin{array}{l}\text { Normal airway mucosa } \\
\text { (on 120th day) }\end{array}$ \\
\hline 8 & $69, \mathrm{~F}$ & $\begin{array}{l}\text { Sarcoidosis, on immune } \\
\text { suppression }\end{array}$ & Piperacillin/tazobactam, Prednisone & Non-reactive & Positive & Negative & $\begin{array}{l}\text { Bilateral interstitial } \\
\text { ground-glass opacities }\end{array}$ & $\begin{array}{l}\text { Bilateral interstitial } \\
\text { ground-glass } \\
\text { opacities }\end{array}$ & $\begin{array}{l}\text { Hyperaemic mucosa } \\
\text { (on 97th day) }\end{array}$ \\
\hline
\end{tabular}

CLL, chronic lymphocytic leukaemia; CT, computed tomography; F, female; M, male; N/A, not applicable; PCR, polymerase chain reaction; TMP-SMX, trimethoprim-sulfamethoxazole.

${ }^{\mathrm{a}}$ Within 7 days before or after biopsy. 
Table 2 SARS-CoV-2 pneumonitis: histological findings in 8 cases of the present series

\begin{tabular}{|c|c|c|c|c|c|c|c|c|}
\hline Case & $\begin{array}{c}\text { Reactive } \\
\text { pneumocytes }\end{array}$ & $\begin{array}{l}\text { Numerous alveolar } \\
\text { macrophages }\end{array}$ & Lymphocytes & Neutrophils & $\begin{array}{l}\text { Plasma } \\
\text { cells }\end{array}$ & $\begin{array}{l}\text { Fibroblastic } \\
\text { foci }\end{array}$ & $\begin{array}{l}\text { Peribronchiolar } \\
\text { inflammation }\end{array}$ & $\begin{array}{l}\text { Viral } \\
\text { cytopathic } \\
\text { effect }\end{array}$ \\
\hline 1 & Present & Focally present & Moderate interstitial lymphocytic infiltrate & Absent & Rare & Present (severe) & Present & Absent \\
\hline 2 & Present & Focally present & Moderate interstitial lymphocytic infiltrate & Absent & Rare & Absent & Present & Absent \\
\hline 3 & Absent & Absent & Moderate interstitial lymphocytic infiltrate & Absent & Absent & Present (mild) & Present & Absent \\
\hline 4 & Absent & Absent & Mild interstitial lymphocytic infiltrate & Absent & Absent & Absent & Absent & Absent \\
\hline 6 & Present & Focally present & Mild interstitial lymphocytic infiltrate & Absent & Absent & Present (severe) & Present & Absent \\
\hline 7 & Present & Absent & Moderate interstitial lymphocytic infiltrate & Absent & Absent & Absent & Absent & Absent \\
\hline 8 & Present & Focally present & Moderate interstitial lymphocytic infiltrate & Absent & Absent & Present (mild) & Present & Absent \\
\hline
\end{tabular}

revealed hyperaemic mucosa with white mucus in the bronchial lumen. All patients re-tested negative for SARS-CoV-2 by PCR within 7 days before or after the day of their bronchoscopies except one (Case 7 showed presence of the virus on 120 th day of the disease). SARS-CoV-2 IgGs were nonreactive in the same time frames for all patients (anti-nucleocapsid assays were performed on the Abbott Alinity; Abbott Diagnostics, USA).

\section{Pathology}

Cryotransbronchial biopsy specimens for all eight cases of SARS-CoV-2 pneumonitis showed an interstitial inflammatory infiltrate (Table 2) that tended to be variable (mild to moderate) and was composed mostly of lymphocytes, with additional rare plasma cells in two cases (Fig. 1). Immunohistochemical studies demonstrated dominant prevalence of CD3 and CD8-positive T-lymphocytes with lesser numbers of the CD4-positive T-cells (Table 3). There were virtually no CD20-positive B-lymphocytes and viral cytotoxic effects. A sensitive and validated immunohistochemistry test for the SARS-CoV-2 nucleocapsid protein, which we performed on lung biopsies, was negative in all cases, indicating that the virus had been cleared from the lungs (Fig. 2).

Additionally, focal epithelial reactive changes were present in five cases, such as pneumocytes with nuclear enlargement. These reactive changes were associated with a focal increase of macrophages in the alveoli. The inflammatory infiltrates were accompanied by mild fibroblastic foci in two (Cases 3 and 8) and severe fibroblastic foci consistent with organising pneumonia in two other cases (Cases 1 and 6) (Fig. 1). Also, peribronchiolar inflammation in some small airways were noticed in five cases. There was no evidence of granuloma, aspiration, and vasculitis. Stains for acid-fast bacilli (AFB) and fungal organisms (GMS) were negative.
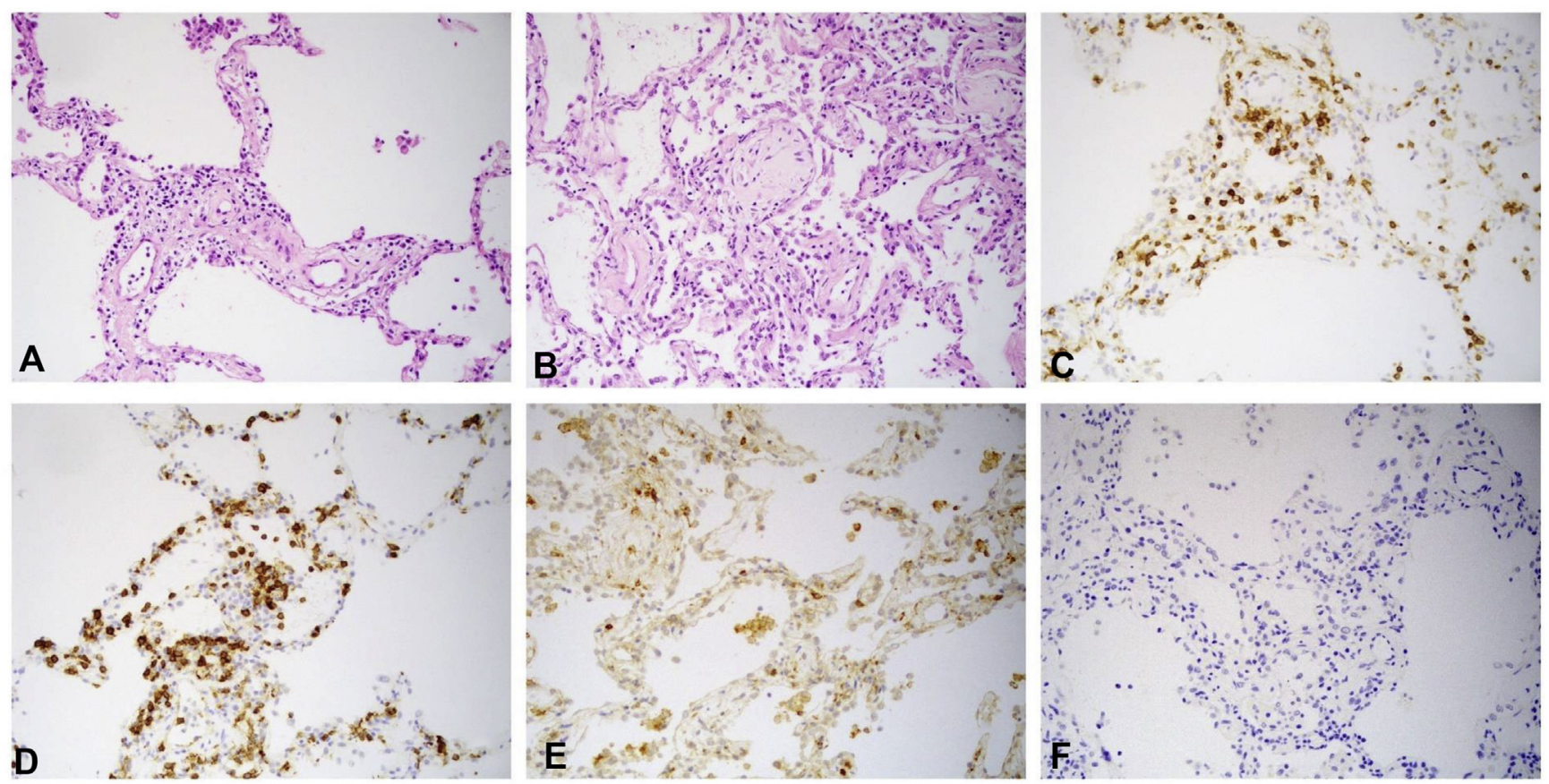

Fig. 1 (A) Interstitial lymphocytic infiltration of the lung (H\&E). (B) Interstitial lymphocytic infiltrate and fibroblastic foci (H\&E). The inflammatory infiltrate consists of (C) CD3-positive T-lymphocytes, (D) predominantly CD8-positive cytotoxic cells, and (E) a minor component of CD4-positive helper cells. (F) CD20-positive B-cells were absent. 
Table 3 SARS-CoV-2 pneumonitis: clinical findings on immunohistochemistry in 8 cases of the present series

\begin{tabular}{|c|c|c|c|c|c|c|}
\hline Case & CD3 & CD4 & $\mathrm{CD} 8$ & CD20 & Plasma cells & SARS-CoV-2 nucleocapsid protein \\
\hline 1 & Present & 1 & 3 & Absent & Rare & Absent \\
\hline 3 & Present & 1 & 3 & Absent & Absent & Absent \\
\hline 4 & Present & 1 & 2 & Absent & Absent & Absent \\
\hline 5 & Present & 1 & 3 & Absent & Absent & Absent \\
\hline 6 & Present & 1 & 3 & Absent & Absent & Absent \\
\hline 8 & Present & 1 & 3 & Absent & Absent & Absent \\
\hline
\end{tabular}
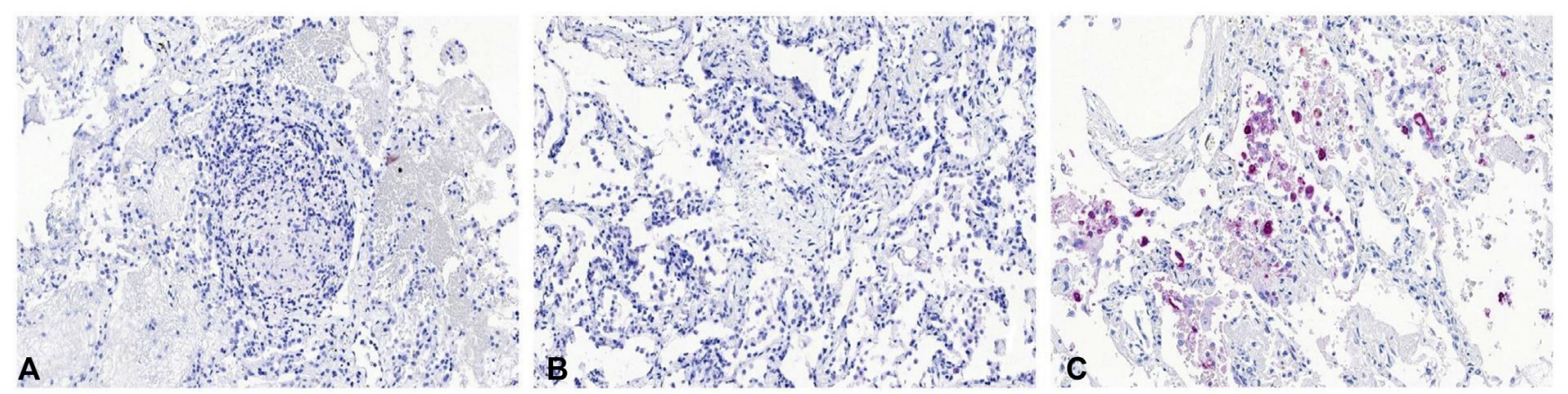

Fig. 2 No residual SARS-CoV-2 was detected in post-COVID-19 lung biopsy from the patients. (A,B) Immunohistochemistry of lung tissue is negative for SARS-CoV2 nucleocapsid protein; (C) positive immunohistochemistry control for SARS-CoV-2 nucleocapsid protein.

Based on these observations, we concluded that the main histopathological finding, such as markedly severe interstitial CD8-positive T-cell lymphocytic infiltration, can be one of the characteristic patterns of SARS-CoV-2 pneumonitis.

\section{DISCUSSION}

The duration of COVID-19, level of SARS-CoV-2 viral replication, and intensity of immune response to viral invasion are important factors in assessing the risks, prognosis, and guiding decisions regarding treatment during the acute and post-acute phases of this infection. Because detection of SARS-CoV-2 RNA is more sensitive and faster than virus isolation, most guidelines have used viral real-time PCR results as a marker for infectious coronavirus.

Detectable SARS-CoV-2 RNA in respiratory specimens persisted 4-6 months (median of 20 days) after disease onset in survivors. ${ }^{3,4}$ However, long-term SARS-CoV-2 shedding was reported in some individuals after their initial positive test. Usually, affected individuals eventually cleared the SARS-CoV-2 infection from the upper respiratory tract after developing neutralising antibody, but the virus was still able to replicate in epithelial cells in the lower respiratory tract, suggesting that it could cause pneumonia or other persistent interstitial lung changes.

Even though only one patient had persistent positivity for COVID-19 longer than one month by RNA-test of nasopharyngeal swab, all patients had areas of interstitial opacities in the lungs during imaging examination up to 6 months after disease onset. Additionally, all eight patients did not show a good immune response to the SARS-CoV-2 virus via nucleocapsid
IgG. A previous study showed that patients with long COVID19 illness exhibited lower levels of neutralising antibodies than patients with shorter durations of this infection. 6

When an immune response is weak or absent, the virus will multiply and massive destruction of the affected tissues will occur, especially in the lungs. The damaged cells induce an intensive response that is primarily mediated by proinflammatory cells and because of this, lung inflammation is the leading cause of life-threatening respiratory disorders at the severe stage of COVID-19 or persistent interstitial lung changes in moderate COVID-19 cases. ${ }^{7}$ Cytokine release syndrome seems to play an important role in patients with moderate to severe conditions, as demonstrated by the high levels of inflammatory cytokines IL-1 and TNF in the lungs of COVID-19 patients. These cytokines are strong inducers of T-lymphocytes and influx of T-cells from the circulation into the site of viral infection. ${ }^{8}$

Lymphocytopenia is often seen in COVID-19 patients in relation to increasing severity of disease. A clinical study also demonstrated that inflammatory cytokines can be used as predictors for COVID-19 severity and survival. ${ }^{9}$ These data correlate with our histopathological examination of the transbronchial biopsies that revealed the dominant infiltration of the lung tissue by CD8-positive T-cells. The virus could be eradicated by CD8-positive T-cells, but in some cases, the very intense activity of these cells induces diffuse alveolar damage that far exceeds the harm that would have been caused by viral replication and induces lethal tissue destruction or irreversible changes like fibrosis. ${ }^{10}$ This has been supported by other findings, which revealed a relation between virus-specific CD8-positive T-cells and lethal SARS 
diseases in infected mice ${ }^{11}$ and documented interstitial mononuclear inflammatory infiltrates in heart tissue in fatal cases of COVID-19. ${ }^{7}$

Notably, we did not find any viral cytopathic effects at the time of lung biopsies. Potentially this can be explained by clearing the virus from the lungs at this time. This was consistent with immunohistochemistry tests for the SARSCoV-2 nucleocapsid protein performed on lung biopsies, which were negative in all patients. Only one patient (Case 7) had positive nasopharyngeal swab RNA-test for SARS CoV2 at the time of the biopsy. We hypothesise that could be reinfection of the upper respiratory tract without new acute involvement of the lungs.

Early cytokine measurements and histological evaluation of the intensity of inflammatory cell infiltration in lung tissue can be reliable predictors of outcome and may help determine which patients are likely to develop respiratory failure or a long-term COVID-19-related pulmonary complication. Once moderate to severe lung damage occurs, efforts should be made to disrupt the underlying pathomorphological events. The lung biopsy may provide substantial insights relevant for patients with ongoing and eliminated SARS-CoV-2 infection by recognising acute and chronic histopathological changes in the lungs. This can open the possibility of initiating appropriate treatment to prevent prolonged proinflammatory responses and potentially further progression of pulmonary fibrosis. ${ }^{12}$

We have described a novel lung injury pattern associated with SARS-CoV-2 pneumonitis which manifests as a marked interstitial CD8-positive T-cell lymphocytic infiltration. Our findings provide a better understanding of the changes in the lungs due to SARS-CoV-2 infection. Ideally, this information will contribute to the improvement of clinical outcome in COVID-19 patients.

Acknowledgements: The authors wish to acknowledge assistance from Brian Y. Chung in text editing.
Conflicts of interest and sources of funding: The authors state that there are no conflicts of interest to disclose. This research did not receive any specific grant from funding agencies in the public, commercial, or not-for-profit sector.

Address for correspondence: Andrii Puzyrenko, MD, Medical College of Wisconsin, Pathology Department, 9200 W Wisconsin Avenue, Milwaukee, WI 53226, USA. E-mail: apuzyrenko@mcw.edu

\section{References}

1. Puzyrenko A, Felix JC, Sun Y, Rui H, Sheinin Y. Acute SARS-CoV-2 pneumonitis with cytotoxic CD8 positive T-lymphocytes: case report and review of the literature. Pathol Res Pract 2021; 220: 153380.

2. Sun Y, Ge L, Rau M, et al. Sensitive and specific immunohistochemistry protocols for detection of SARS-CoV-2 nucleocapsid and spike proteins in formalin-fixed, paraffin-embedded COVID-19 patient tissues. Res Square 2020; Jul 16: https://doi.org/10.21203/rs.3.pex-1011/v1.

3. Fu Y, Han P, Zhu R, et al. Risk factors for viral RNA shedding in COVID-19 patients. Eur Respir J 2020; 56: 2001190.

4. Zhou F, Yu T, Du R, et al. Clinical course and risk factors for mortality of adult inpatients with COVID-19 in Wuhan, China: a retrospective cohort study. Lancet 2020; 395: 1054-62.

5. Avanzato VA, Matson MJ, Seifert SN, et al. Case study: prolonged infectious SARS-CoV-2 shedding from an asymptomatic immunocompromised individual with cancer. Cell 2020; 183: 1901-1912.e9.

6. Ho M-S, Chen W-J, Chen H-Y, et al. Neutralizing antibody response and SARS severity. Emerg Infect Dis 2005; 11: 1730-7.

7. $\mathrm{Xu} \mathrm{Z}$, Shi L, Wang Y, et al. Pathological findings of COVID-19 associated with acute respiratory distress syndrome. Lancet Respir Med 2020; 8: 420-2.

8. Ragab D, Salah Eldin H, Taeimah M, Khattab R, Salem R. The COVID19 cytokine storm; what we know so far. Front Immunol 2020; 11: 1446.

9. Del Valle DM, Kim-Schulze S, Huang H-H, et al. An inflammatory cytokine signature predicts COVID-19 severity and survival. Nat Med 2020; 26: 1636-43.

10. Coperchini F, Chiovato L, Croce L, Magri F, Rotondi M. The cytokine storm in COVID-19: an overview of the involvement of the chemokine/ chemokine-receptor system. Cytokine Growth Factor Rev 2020; 53: 25-32.

11. Zhao J, Zhao J, Perlman S. T cell responses are required for protection from clinical disease and for virus clearance in severe acute respiratory syndrome coronavirus-infected mice. J Virol 2010; 84: 9318-25.

12. George PM, Wells AU, Jenkins RG. Pulmonary fibrosis and COVID-19: the potential role for antifibrotic therapy. Lancet Respir Med 2020; 8: 807-15. 